\title{
Selection of film for modified atmosphere packaging of chillies (Capsicum annuum L.) based on permeability
}

P.S. GREWAL, ASHOK KUMAR AND PREETINDER KAUR

Received : 21.03.2017; Revised : 11.07.2017; Accepted : 25.07.2017

See end of the Paper for authors' affiliation

Correspondence to :

\section{P.S. GREWAL}

Depertment of Processing and Food Engineering, Punjab Agricultural University, LUDHIANA (PUNJAB) INDIA Email : pawan-coaepfe@pau. edu
- ABSTRACT : The design of MAP requires thorough understanding of characteristics and effects of packaging material on fresh produce during storage.Film permeability declines with reduction in temperature of different films (LDPE, HDPE and PP). The rates of oxygen consumption and carbon dioxide evolution increases with rise in temperature $\left(5,10\right.$ and $\left.15^{\circ} \mathrm{C}\right)$. The $\mathrm{O}_{2}$ and $\mathrm{CO}_{2}$ permeability per unit thickness increased as temperature increased. All the films had lower permeabilities than required. So 10,15 and 20 perforations were made in the film of highest permeability i.e. LDPE was selected for packaging of chillies under modified atmosphere packaging.

— KEY WORDS : Packaging, Permeability, Modified atmosphere packaging, Chillies

- HOW TO CITE THIS PAPER : Grewal, P.S., Kumar, Ashok and Kaur, Preetinder (2017). Selection of film for modified atmosphere packaging of chillies (Capsicum annиum L.) based on permeability. Internat. J. Agric. Engg., 10(2) : 287-290, DOI: 10.15740/HAS/IJAE/10.2/287-290. 